\title{
Synchronous Examination of Diaspora Communities: Slovenian Canadians in Ontario
}

\author{
Alenka Čuš \\ Department for Slovenian Studies (Slovenian Language and Literature), Faculty of Humanities, University of Primorska, Slovenia
}

Copyright $(2018$ by authors, all rights reserved. Authors agree that this article remains permanently open access under the terms of the Creative Commons Attribution License 4.0 International License

\begin{abstract}
This article presents a model for studying diaspora communities as independent structures applied to the Slovenian-Canadian case and where the synchronous examination of diaspora communities and the literary system is the central subject of study. This paper presents an established research model, which does not examine diaspora communities as a bridge between the country of origin and the country of acceptance, but as a third autonomous, equivalent space. The model enables extra and intratextual analysis of literature, treatment of written and spoken language use and examination of formal and informal institutional situations of the diaspora community. This methodology is especially effective in the analysis of the diaspora community under contemporary conditions, where we find only the remnants of a once powerful system that have managed to be maintained over many decades up to the present, which is not possible from a distance (e.g. from Slovenia). Using the researcher's two years of fieldwork as well as the intra-community status of the researcher, the community was observed with the taxonomy of variables proposed by Howard Giles et al. (1971) that determines the empirical reality of minority communities. Due to the shortcomings of this approach in the analysis, we have established a more appropriate model, which not only enables the monitoring and assessment of the community, but on the basis of the theory of realization of national interpellation proposed by Marcello Potocco (2012), we are able to increase the actual vitality and strengthen the (Slovenian) national identity. The model allows participation in the activity, not only for observing, but for implementation of additional activity as well, according to the existing situations and needs of the community. The vitality of the community was re-assessed and the results compared with the pilot assessment. The comparison demonstrated that the proposed approach is effective. In the Slovenian community, in Ontario, the material factors of national interpellation are: socio-institutional context (interconnection of institutions), education, media, literary system (extra and intratextual), publishing market, the use of language (written, spoken) and other (religion, economy, music, sport and
\end{abstract}

gastronomy).

Keywords Vitality Assessment, Slovenian Canadian Diaspora Community, Realization of the National Interpellation, Enhancement of the Slovenian National Identity in Ontario

\section{Introduction}

Before 1920 very few Slovenians settled in Canada, and arrived via the United States. Among them was missionary Frederic Baraga (1797-1868), who, in 1857, became the first Bishop of Sault Ste. Marie. The first wave of Slovenian immigration to Canada was organized by travel agencies that were actively seeking healthy young men to work on farms in Manitoba and Saskatchewan and on the railways in British Columbia. As soon as they had fulfilled their obligation, they moved to towns where Slovenians began to concentrate. Before WWII an estimated 4,600 Slovenians lived in Canada. The most vibrant Slovenian community was in Kirkland Lake, Ont, where in 1933 the first independent Slovenian benefits society was established. The geographical distribution of Slovenians changed drastically during and after WWII, partly due to the resettlement of Slovenians from the mining towns of northern Ontario to farms in the Beamsville and St. Catharines area. Also, between 1947-51, a large number of political refugees arrived and after a year of obligatory work duty, began to settle mainly in urban areas, especially Toronto and Hamilton. The third wave of Slovenian immigrants came to Canada between 1951-60, mostly family members of pre- and postwar immigrants, as well as young men and women who were unable to find employment in their homeland. Between 1960-70, many more Slovenians came to Canada for economic reasons. Most of them settled in Ontario, namely in Toronto, Mississauga, Hamilton, St. Catharines, Kitchener, London, Windsor, Ottawa, Thunder Bay and Oshawa. There are also vibrant Slovenian communities in Montreal, 
Vancouver, Victoria, Port Alberni, Kelowna, Prince George, Calgary, Edmonton, Lethbridge and Winnipeg, as quoted by Cvetka Kocjančič [1], but the political center of all Slovenians in Canada resides in southern Ontario, and therefore the field work was performed there as well. The community of Slovenians in Canada ${ }^{1}$ is based on volunteer work to preserve and enhance the Slovenian national identity in variety of religion, education, music and sport activities. Today, in the province of Ontario, there exist more than thirty Slovenian organizations which are connected through an umbrella organisation, the Vseslovenski Kulturni Odbor (VSKO) or, in English, the All Slovenian Cultural Committee (ASCC) based in Toronto. There is another umbrella sub-organisation, the Slovenski Koordinacijski Odbor Niagara (SKON) for the Southern Ontario / Niagara Peninsula region which works together with VSKO and three Slovenian Parishes, two in Toronto (Our Lady Help of Christians and Our Lady of the Miraculous Medal) and one in Hamilton (St. Gregory the Great). „All Slovenian Priests are cultural workers simultaneously, and therefore the role of Slovenian Church is essential at preserving Slovenian identity in Canada« notes Jože Plevnik [4]. Organisations mostly have their own halls, presidents and boards operating autonomously for their own region first, and only then they cooperate when needed, usually for hosting Slovenian polka music bands from Slovenia, when they split the obligations and expenses. Rado Genorio [5] at the end of the 1980's classifies institutions of Slovenian Canadians in the field of geography as: social-solidarity ones, church, political and cultural institutions. Organizations leading activities Genorio divides as cultural, educational, social, sports/recreational, folklore dances, economic, and mass media as other.

The first scientific research of Slovenian Canadians Literature and Media in Slovenia was made by Mirko Jurak in the second book of Slovenian Diaspora Literature in 1999. Jurak [6] notes the high importance of magazines and newspapers for preserving Slovenian language and culture in Canada. Slovenian Canadian Literature quotes that there are many writers with only one work, and that authors in general mostly publish their short stories in media, which usually are very much autobiographical, comparing life in Canada with Slovenia or what is happening in Canada, but there are a lot of memories from

\footnotetext{
1 "The Slovenians are a Slavic people whose main homeland was recognized in 1991 as the independent Republic of Slovenia. However, large indigenous ethnic minorities of Slovenians still live in Austria, Italy and Hungary. The exact number of Slovenians in Canada cannot be determined, since no records of their emigration were kept and no reasonable data were obtained by the Canadian census. According to one estimate, approximately 40000 Slovenians of first, second and third generation live in Canada. The 2006 census reported more than 36000 Slovenians in Canada"[2]. As the focus of the study is macro-sociolinguistic (institutional and collective) operation of a diaspora community, we do not examine all Slovenians living in Canada, but only active members of the community. Similarly Cvetka Kocjančič [3] already concluded in 1999: "Even though there is app. 20000 Slovenians living in Ontario, there is only 500 to 700 regular visitors of the concerts."
}

the homeland in between. Janja Žitnik Serotin [7] in Večkulturna Slovenija (Multicultural Slovenia) notes that Slovenian Diaspora Literature in general (all settlement islands abroad) in homeland Slovenia was published between 1991-1993, but before and after the numbers are only lower. There is much published and unpublished material with documentary sources by Cvetka Kocjančič, a central Literature author and publicist, and long-term cultural volunteer worker of the community - to understand the study problem from a Slovenian Canadian perspective. She started writing poems, but later published two biographical novels Uporniks čopičem (1992 in Slovene)/ Unhappy Rebel (1994 in English) and Gospodar golega ozemlja (The Master of Arid territory)1996, and a book of memories in short stories Kam vodi cesta (Where the Road lead) in 2015. In the archives, there was a major research completed by Milica Trebše Štolfa on Slovenian Canadian societies all over Canada since 1986 for the Archives of Republic of Slovenia. Based on archive reviews of a few individual organisations, for example in Ontario she published: SPD Simon Gregorčič: 1959-1989= Slovenian Cultural Association Simon Gregorčič: 1959-1989 (1989) and 50 let dela in spominov VPZ Bled, Odsek št. $13-$ Planica, Hamilton, Ontario, Kanada: 1943-1993 / 50 years of work and memories VPZ Bled, Section no. 13 Planica, Hamilton, Ontario, Canada (1993). The last one was published in Slovenia as well: Ohranjanje slovenske kulturne tradicijel Preservation of Slovenian Cultural Tradition, Slovensko kulturno društvo Sava/Slovenian Association Sava, Kitchener to Breslau, Ontario, Canada (2016). In the field of (oral) history there was made a doctoral dissertation by Urška Strle, based on field work and individual thematic interviews: Slovenci v Kanadi: izseljevanje skozi prizmo življenjskih zgodb/Slovenians in Canada: emigration in the prism of life stories (2009). The position of the Slovenian Church was reported by Jože Plevnik (Cerkev in slovenska identiteta $v$ Kanadi/Church and Slovenian identity in Canada, 1997) and Blaž Potočnik (Med Slovenci v Kanadi/Among Slovenians in Canada, 2000). These authors are especially relevant because of their field work. There were also a few bachelor and masters degrees made in Slovenia, based on literature and/or questionnaires send to Canada, for example by Alenka Starman (Multikulturalizem $v$ Kanadi/ Multiculturalism in Canada, 2004), Teja Bitenc (Slovenska izseljenska društva in ohranjanje slovenstva $v$ Kanadi in na Švedskem/ Slovenian Diaspora Communities and preserving Slovenianhood in Canada and Sweden, 2009), Stanislav Pospeh (Slovenska imigracija v Kanadi/Slovenian immigration in Canada, 2009).

Urška Strle [8] notes that Slovenians in Canada were usually put together with Slovenians in the United States, although they have a completely different background in the country of acceptance. In another source Strle [9] quotes that »The reasons for this may be found in the fact that compared to the United States, Canada was generally 
less distinguished and offered poorer economic and living conditions «, but there were not any major research projects made on the differences between Slovenians in Canada and the United States. There was only Nada Šabec, who studied Slovenian-English language contact and language change within Slovenians on the North American continent in general (Half pa pu: the language of Slovene Americans, 1995) and many other articles on language of Slovenians in different cities in both countries. In Canada Multiculturalism $^{2}$ was legalized in 1971, and we presume that the most visible difference between mentioned countries in their migration policy is that the USA is using

\footnotetext{
2 "As a sociological fact, multiculturalism refers to the presence of people from diverse racial and ethnic backgrounds. Ideologically, multiculturalism consists of a relatively coherent set of ideas and ideals pertaining to the celebration of Canada's cultural diversity. At the policy level, multiculturalism refers to the management of diversity through formal initiatives in the federal, provincial, territorial and municipal domains. /... / Canada's history of settlement and colonization has resulted in a multicultural society made up of three founding peoples - Aboriginal, French, and British - and of many other racial and ethnic groups. / ... This increased diversity was evident in the 2011 National Household Survey, in which more than 200 different ethnic origins were reported. /.../ Analysts generally agree that federal multiculturalism policy has evolved through three developmental phases: the incipient stage (pre-1971), the formative period (1971-1981), and institutionalization (1982 to the present). /... These recommendations led to the introduction in 1971 of the Multiculturalism Policy. Its key objectives were these: to assist cultura groups to retain and foster their identity; to assist cultural groups to overcome barriers to their full participation in Canadian society (thus, the multiculturalism policy advocated the full involvement and equal participation of ethnic minorities in mainstream institutions, without denying them the right to identify with select elements of their cultural past if they so chose); to promote creative exchanges among all Canadian cultural groups; and to assist immigrants in acquiring at least one of the official languages (English or French). /.../ The architects of the 1971 Multiculturalism Policy had perceived barriers to social adaptation and economic success largely in linguistic or cultural terms. /.../ Equality through the removal of racial discriminatory barriers became the main focus of multicultural programs, and race relations policies and programs were put in place to uncover, isolate and combat racial discrimination at personal and institutional levels. /.../ (Programs and acts on Multiculturalism were changing through history, and so did Ministry for Multiculturalism and its sections.) /.../ Following increased criticism of the multiculturalism program voiced by various groups and individuals from different parts of Canadian society, the Department of Canadian Heritage launched a comprehensive review of its multiculturalism programming activities in 1995. In 1997, the Secretary of State for Multiculturalism announced a renewed program that focused on three objectives: social justice (building a fair and equitable society); civic participation (ensuring that Canadians of all origins participate in the shaping of our communities and country); and identity fostering a society that recognizes, respects and reflects a diversity of cultures so that people of all backgrounds feel a sense of belonging to Canada). /.../ Indeed, attitudes towards immigration and multiculturalism have become more positive over the years. According to the Focus Canada surveys conducted by the Environics Institute for Survey Research, the percentage of Canadians who see multiculturalism as a symbol of Canadian identity increased from $37 \%$ in 1997 to $56 \%$ in 2010 . /.../ Attitudes towards multiculturalism vary from region to region. In particular, many Quebecois have expressed uneasiness about, or even resistance to, federal multiculturalism policy since its inception. /.../ In addition, some commentators have expressed the fear that the multiculturalism policy is promoting too much diversity at the expense of unity. Critics say the policy is divisive because it emphasizes what is different, rather than the values that are Canadian. /.../ On the other hand, defenders of Canada's approach to multiculturalism argue that it encourages integration by telling immigrants they do not have to choose between preserving their cultural heritage and participating in Canadian society. Rather, they can do both. /.../ Recent polls show that multiculturalism is largely seen in a positive light. In a review of public opinion research on attitudes towards multiculturalism from 2006 to 2009 Stuart Soroka and Sarah Roberton found that multiculturalism is "viewed as an integral and largely positive aspect of the Canadian state," as is cited by Michael Dewing[10] on Canadian Multiculturalism.
}

assimilation programs, and that Canada uses integration programs:» The Commission ${ }^{3}$ recommended the »integration« (not assimilation) into Canadian society of those ethnic groups with full citizenship rights and equal participation in Canada's institutional structure. «[11] Based on the last report of Citizenship and Immigration Canada (CIC) by William Kymlicka entitled The current State of Multiculturalism in Canada and research themes on Canadian Multiculturalism 2008-2010, there are ten areas connected to multiculturalism and migrants in Canada that most need examination. Kymlicka [12] noted patterns of ethnic community formation as one of the most relevant area in need of research. He claims that Canada does not have enough evidence on the structures of ethnic community formations nor their changes over time: "We do not know the institutional structures that exist within these communities, such as ethnic media, religious organizations, financial organizations, recreational organizations, educational organizations, political and advocacy organizations." In Slovenia, Strle [13] notes that there is an emphasis on research related to Slovenians in Argentina and Australia and a huge deficit relating to Slovenians in Canada. Therefore, the methodological examined the unexplained problem for both Canada and Slovenia with the central case of the study of the macro-sociolinguistic (institutional and collective) operation of the Slovenian Diaspora Community in Ontario, Canada in the period of 2014-2015.

\section{Methods}

The study examined a specific diaspora community with an applied approach, the method of pragmatism. The core of its process, according to William James [14], is to trace practical consequences. The pragmatic method derives from tracking the structure of reality and the structure of our experience of reality [15], where reality is open, vulnerable, unfinished, and where the subject comes to finish it by Šimenc [16]. James [17] sees pragmatism as a view into the future, as opposed to rationalism, which looks back into the distant past. Therefore pragmatism enables an empirical approach, which by James [18] »turns the view to the reality and compliance, facts, operation and power«. The study determined the areas to observe in the structure of the reality of the Slovenian Diaspora Community in Ontario according to the model of ethno-linguistic vitality proposed by Howard Giles et al., more precisely the so-called Taxonomy of objective structural variables, which directly represents the empirical reality of a minority group. As cited in Albina Nećak Lük[19] there are three kinds of variables: status variables (advocacy, political, economic, social, socio-historical and language status (within, without)), demographic variables (national

3 The Royal Commission on Bilingualism and Biculturalism, in 1969. 
territory, concentration, proportion, absolute, birth rate, mixed marriages, immigration, emigration), and variables of institutional support (national or their own institutional support, mass media, education, government services, industry, religion, culture, contacts with country of origin). Giles, in his proposal, besides these variables, suggests acknowledgement of the subjective view as well, with a questionnaire for the inside and outside members of the observed minority group. During the two years of field work, the questionnaire approach was substituted with active fieldwork in the community using a pragmatic method (existing actions and implementing new ones) leaning on the so-called Participatory Design [20], "an approach to design attempting to actively involve all stakeholders (e.g. employees, partners, customers, citizens, end users) in the design process to help ensure the result meets their needs and is usable". By Sonya Corbin Dwyer and Jennifer L. Buckle [21] "many feminist researchers have advocated for a participatory model 'Reinharz, 1983, cited in Cotterill, 1992) that aims to produce "non-hierarchical, non-manipulative research relationships which have the potential to over-come the separation between the researcher and the researched" (p. 594). To make interviewing an interactive experience, researchers are invited to bring their personal role into the research relationship by answering participants' questions, sharing knowledge and experience, and giving support when asked (Oakley, 1981, cited in Cotterill, 1992)."

In 2013, it was determined that 2014 and 2015 is the period of observation and active work on the field. Due to the of lack of statistical data or material on contemporary conditions to examine the diaspora community inside its homeland Slovenia, nor refraction from the distance (online), it was decided to access it with direct contact and qualitative methods: observation and inclusion in the activities. Initially, the researcher was involved in the organized activities as a regular visitor and noted that communication inside or between organizations were happening mostly informal and hidden and oral, not written. Communication processes were minimal, due to the observation of very well established annual events, and the information needed was more or less self-understood, after decades of implementation. However that also meant, the events rarely do anything to attract new members to the community. As a visitor of the communities' activities, in all areas, the researcher could not reach the information needed for the research on institutional operation either, until after the involvement in the institutional communication processes as an active volunteer member in different areas, mostly education and media, but in all activities at least as a visitor. As James[22] argue, pragmatist clasps the facts and concreteness, observe the truth at work in individual cases and generalize it, making it possible to evaluate the diaspora community and its ethno-linguistic vitality by Giles. The institutional processes observed are dynamic and changes throughout the history, and for example, differs in the years of 1991 from 1984, or 2011 from 2013 or 2016. This is why it is very important to determine fieldwork by exact time frame, although the activities in all areas were not started at the same time:

A Preliminary analysis 2011-2013

B Empirical approach on the field 2014-2015

1. rate (November 2013-January 2014): observing and participating at the activities of the community as a regular visitor, aspect of a researcher from their homeland;

2. rate (February 2014-March 2014): integration inside the working processes of the institutional operation of the community in different areas;

3. rate (April 2014-June 2014): transitional period and active participation;

4. rate (July 2014-September 2014): trust and insides gained;

5. rate (October 2014-December 2014): phase of complete access and possible decision making.

C Movement 2015 - move from the Slovenian Canadian perspective to the Canadian perspective (from Toronto, ON to Regina, SK), but still involved with the field over media as editor-in-chief.

D Movement 2016 - move from Canadian perspective back to homeland Slovenia to gain objectivity and to conclude analysis in Slovenia, intended for Slovenian perspective (but still involved in the field over media).

This way the research framed the examination by calendar, but analyzed activities by areas. For appropriate qualitative research the researcher derived from the study of Corbin Dwyer and L. Buckle, The Space Between: On being an Insider-Outsider in Qualitative Research (2009) where the authors in ethnography examine the advantages and disadvantages of being a researcher with outsider or insider status. Corbin Dwyer and L. Buckle[23] cite Rose (1985) that at such a research approach there is no neutrality, only less or greater awareness of one's biases: »Adler and Adler (1987) identified three »membership roles «of qualitative researchers engaged in observational methods: (a) peripheral member researchers, who do not participate in the core activities of group members; (b) active member research, who become involved with the central activities of the group with fully committing themselves to the members' values and goals; and (c) complete member researchers, who are already members of the group or who become fully affiliated during the course of the research." Based on Adler and Adler the researcher defined her status of researcher as a complete member, which was gained gradually over both a peripheral and active member's role, and even then only after intensive engagement and trust proven. The researcher was also shared the fundamental experience to the other members of the community because of her personal immigration experience to Canada. To understand complete status of being inside of the Slovenian Canadian community also contribute the same intention to 
preserve and encase Slovenian identity, that is in common to all Slovenian Canadians (the researcher operated in the community of her own nation and not some other one), with a common way of contribution (volunteering), and spending free time together on the weekends, based on the foundation of "family ties". This method gained values and traditions of Slovenian Canadians over time however another consideration in the field research approach was that of an independent researcher from any research institution in Slovenia. Otherwise, the access to the (oral and written) material would most likely be much more limited. As Strle [24] already noted on the same field, there was resilience to participate with researchers. For a complete member research role, which by Adelin (2003) means that the researcher shares an identity, language, and experiential base with the study participants, Corbin Dwyer and Buckle[25] quotes that this »frequently allows researchers more rapid and more complete acceptance by their participants. Therefore, participants are typically more open with researchers so that there may be a greater depth to the data gathered." In this perspective, if we justify the subjective view to the empirical reality of the observed community, the authors[26] claims that as inside researchers we are not better or worse, but different, and that definitely there is emotional aspect involved in the fieldwork. This is why by Kanuha (2000) one must pay special attention to the objectivity and authenticity. Watson and Armstrong also notes that all these criteria can bring to conflicts or influent researchers perception, and that in the field it is highly relevant to avoid conflict situations, which on the field work of this study was only confirmed. Corbin Dwyer and Buckle [27] claimed that the status of an outside researcher should bring to the research especially the width, as we tried to do with the movement outside of the community to Canadian or back to Slovenian perspective. Authors also quoted Acker (2000) asking herself if is better to be inside or outside researcher, and the authors sets the question as difficult to deal with. Corbin Dwyer and Buckle [28] recommends finding the ways to put ourselves into both positions, which was the case. Based upon our own field work, this researcher would even recommend using both researchers' roles. Both methods are equally important to use, to gain knowledge on the problem from all three perspectives, Slovenian, Canadian and Slovenian-Canadian.

\section{Pilot Assessment and limitations}

In 2013 the researcher did a pilot vitality assessment of the Slovenian Diaspora Community in Ontario based on previous work in Seminars by Čuš [29] and therefore available materials in Slovenia, and a ten day visit with Slovenians in Ontario at the end of April. The status variables were evaluated with a mark of medium vitality and institutional support with a mark of medium low. Because of lack of data, a measurement of demographic variables was not at all possible, not even later on.

Table 1. Pilot vitality assessment of the Slovenian-Canadian case in Ontario in 2013

\begin{tabular}{|c|c|c|}
\hline Status variables & Demographic variables & Institutional support \\
\hline $\begin{array}{l}\text { Advocacy status } \\
\mathbf{M}\end{array}$ & $\begin{array}{c}\text { National territory } \\
\text { MH }\end{array}$ & $\begin{array}{c}\text { National or their own institutional support } \\
\text { M }\end{array}$ \\
\hline $\begin{array}{c}\text { Political status } \\
\text { ML }\end{array}$ & Concentration, proportion & $\begin{array}{l}\text { Mass media } \\
\quad \text { ML }\end{array}$ \\
\hline $\begin{array}{c}\text { Economic status } \\
\mathbf{M}\end{array}$ & $\begin{array}{c}\text { Absolute } \\
/\end{array}$ & $\begin{array}{l}\text { Education } \\
\quad \text { ML }\end{array}$ \\
\hline $\begin{array}{l}\text { Social status } \\
\text { M }\end{array}$ & $\begin{array}{c}\text { Birth rate } \\
/\end{array}$ & $\begin{array}{c}\text { Government services } \\
\text { ML }\end{array}$ \\
\hline $\begin{array}{c}\text { Socio-historical status } \\
\text { M }\end{array}$ & $\underset{/}{\text { Mixed Marriages }}$ & $\begin{array}{c}\text { Industry } \\
\mathbf{L}\end{array}$ \\
\hline \multirow[t]{4}{*}{ Language status: - within L - without L } & Immigration, emigration & $\begin{array}{l}\text { Religion } \\
\mathbf{M}\end{array}$ \\
\hline & & $\begin{array}{c}\text { Culture } \\
\mathbf{M}\end{array}$ \\
\hline & & $\begin{array}{c}\text { Contacts with country of origin } \\
\text { M }\end{array}$ \\
\hline & VITALITY ASSESSMENT: & \\
\hline $\mathbf{M}$ & 11 & ML \\
\hline
\end{tabular}

Legend: $\mathrm{L}=$ low, $\mathrm{ML}=$ =medium low, $\mathrm{M}=$ =medium, $\mathrm{MH}=$ =medium high, $\mathrm{H}=$ high vitality 
Therefore the vitality assessment based on the Giles model was not possible as a whole. Only after some time and through the insider status of the research in the field were other shortcomings noted of the Giles model as well. It is absolutely focused on written language and therefore formal situations, which is appropriate if we examine a diaspora community diachronically, but not when we analyze its contemporary conditions, when working processes are mainly resolved hidden and, in spoken language, informally. To the gap between formal and informal conditions already warned other researchers in Slovenia (for example Žitnik Serafin [30] and Strle [31]), therefore the researcher explicitly wanted to reach authentic results from the field, and focus on informal conditions especially. Furthermore, the model, which is clearly intended to examine minority groups, observes the diaspora community from the majorities' perspective rather than as an independent structure and its interests not the ones from the country of origin nor country of acceptance. Miller and Druin [32], based on participatory design, establishes third space in information technology (IT) with the thesis on post-colonial theories and Bhabha (1994), that »the border or boundary region between two domains - two spaces - is often a region of overlap or hybridity - i.e. a »third space« that contains an unpredictable and changing combination of attributes of each of the two bordering spaces / .../ creates a new hybrid or third culture (Bhabha 1994)". Miller and Druin [33] also cited Evanoff (2000) and his terms third culture, third perspective and third area. Based on these facts we can determine broad research space into three perspectives: country of origin Slovenia, country of acceptance Canada, and Slovenian-Canadian community. Based on the researcher's observations in the diaspora field, I claim that areas that negotiate and co-create the third space according to Michael Muller[34] are basic areas to observe and analyze the institutional operation of a diaspora community as a third autonomous space. At the same time this approach is used for the needs of the subjective view for the Giles model to cover the informal field. These areas are: (1) Identities, (2) Working language, (3) Working assumptions and Dynamics, (4) Understandings and Relationships, and (5) Collective actions.

To examine Diaspora community as independent third structure is now presented as highly relevant, especially since gaining the complete member role of researcher in the community and deriving from within. Thus the Giles model is no longer suitable for the analysis of actions, however the researcher still suggests using it for selecting areas for observations in the field. But the basic principle of the study is the use of pragmatic method, which enable us to trace the structure of reality for ethno-linguistic vitality assessment, but because of the look in the future also to influence its empowerment where possible, with what by James[35] »the theories become tools.«

\section{Solution}

Suddenly, when a researcher becomes a complete member of the community, and at the same time, examine certain community not from the majority's perspective, but from the inside, Slovenian Canadian perspective in this case, the interest is not only in the facts connected with how the Slovenian national identity is preserved, but more importantly, in the possibilities for its enhancement. Therefore new goals of the study were set up: how can researchers reach the enhancement? Parallels for strengthening and empowering national identity can be found in the work of Marcello Potocco, and in the (non-)realization of the ideological function or so called national interpellation. Potocco [36] puts together imaginary, ideology and literature in answering the question of how ideology exists in the structure of a literary work. According to Bogdan Lešnik [37] national interpellation means actions in practice, based on the fact that Althusser already sees ideology as the social tissue and as all kinds of rituals forming material parts of the ideological state apparatus, such as a mass in the church, an ordinary soccer match in the local sports association or a school day in some school. Potocco in his research analyzes the material factors for a realization of the ideological function of national interpellation for the structure of a nation as majority in the richest times of state forming. As researchers, are able to draw a model of these material factors: socio-historical development; the school system; the publishing market and literary field; and intra-textual analysis of literature with documentary sources. 


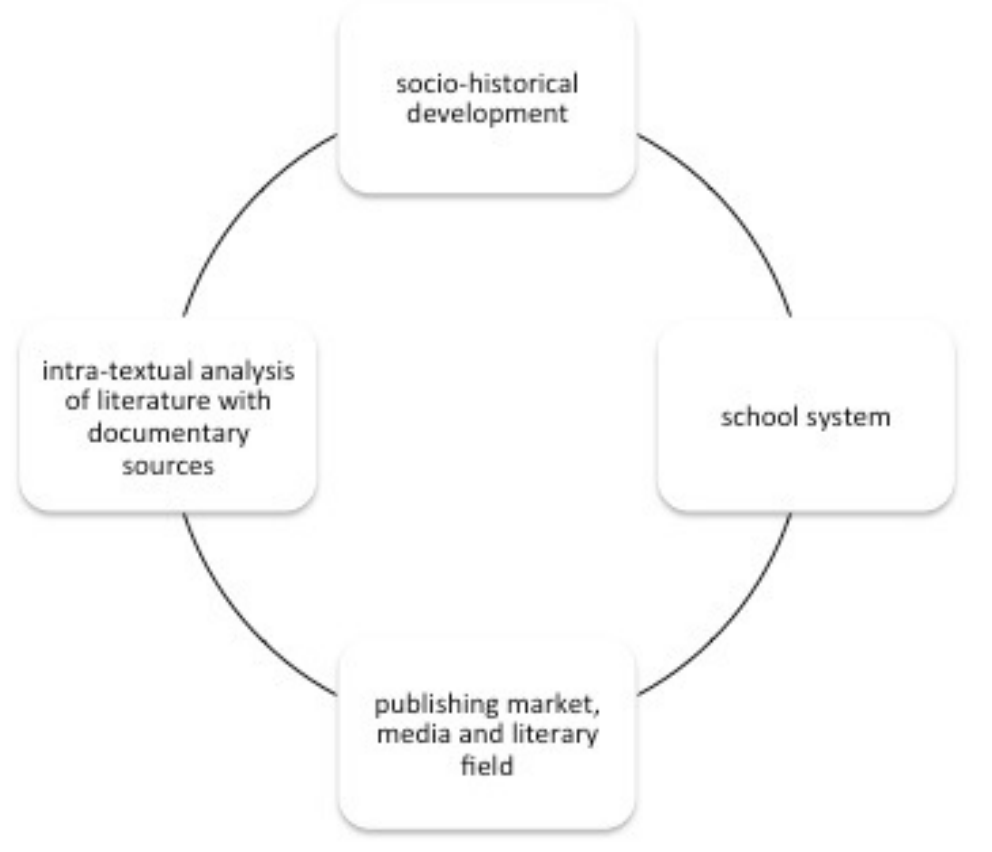

Model 1. Model of material factors of national interpellation by Marcelo Potocco (2012)

At first glance these factors are similar to the variables of Giles' Taxonomy and Miller's subjective view, which we use in sociolinguistics. But because the central study here becomes literature using these methods as well, the enhancement of national identity is examined in a completely different way. It is no longer based only on observation and a vitality assessment of its empirical reality any more, but it is about actions of addressing it in practice, as Lešnik said. With this kind of approach we are not only observing, but we can strengthen the existing actions, and add new ones. Furthermore, the internal status of the researcher enables us to insert appropriate resolutions for the authentic needs, because we have the possibility of seeing and understanding them in operation. A literary approach is based on imaginary and ideology, while a sociolinguistic one is based on empirical reality and institutions. On one hand, Giles' model examines a minority group from the perspective of the majority nation; on the other hand Potocco's model examines it from the inside and as an independent structure. Because Potocco's model offers us solutions for the existing trouble with the Giles model, which is the evidence that Potocco's material factors of national interpellation are exactly suitable for examining the preservation and enhancement of the national identity, even though we are examining a diaspora community. For the Canadian and Slovenian case Potocco [38] notes that they both arise from the general paradigm of European and Non-European cultural nationalism, which means that the type of construction of the nation is not based on political-territorial or state unity, but in the principle of ethnic and cultural origin. This can be applied to a present diaspora community as well.

Table 2. Preserving and strengthening national identity

\begin{tabular}{|c|c|}
\hline \multicolumn{2}{|l|}{ Preserving and strengthening national identity } \\
\hline SOCIOLINGUSTICS & LIT. HISTORY \\
\hline $\begin{array}{l}\text { Ethnical-linguistics vitality assessment } \\
\text { Vitality Assessment - variables that determines empirical reality }\end{array}$ & $\begin{array}{l}\text { Actions of national interpellation } \\
\text { Enhancement or raising the vitality }\end{array}$ \\
\hline $\begin{array}{l}\text { Taxonomy of variables by Howard Giles et. al. model, which determines the empirical reality: } \\
\text { Status variables (advocacy, political, economic, social, sociohistorical and language status } \\
\text { (within, without)), Demographical variables (national territory, concentration, proportion, } \\
\text { absolute, birth rate, mixed marriages, immigration, emigration), and } \\
\text { variables of Institutional support (national or their own institutional support, mass media, } \\
\text { education, government services, industry, religion, culture, contact with country of origin (Nečak } \\
\text { Luk 1998, 35) } \\
\text { + subjective view: } \\
\text { Muller areas of Third Space, based on Participatory Design: } \\
\text { (1) Identities, (2) Working language, (3) Working assumptions and Dynamics, (4) Understandings } \\
\text { and Relationships, and (5) Collective actions (Muller and Druin 2003, 12). }\end{array}$ & $\begin{array}{l}\text { Material factors of national } \\
\text { interpellation in Literature by Potocco } \\
(2012) \text { : } \\
\text { - socio-historical development } \\
\text { - school system } \\
\text { - publishing market and literary field } \\
\text { - intra-textual analysis of literature with } \\
\text { documentary sources. }\end{array}$ \\
\hline
\end{tabular}


After the researcher spent time doing field research in the Slovenian Diaspora Community, in Ontario, it is clear that what has been stated is not quite true and that while observing a minority group we have to be more precise. The main factors can be weaker, when national interpellation in a diaspora community is realized in other areas as well. Through empirical checking of Potocco's model in contemporary practice it has been determined that material factors of national interpellation, specifically for a Diaspora Community. In an applied approach all the possible activities of the community are compiled and then able to look for answers as to when and how the national interpellation is realized. The results of empirical checking at first look similar to the notes of Potocco, even though in this research scenario the examination of a diaspora community in contemporary period of time, it is true that the strongest material factors still are the school system, literary institution and the socio-institutional context (by Potocco's model socio-historical development). Despite this it needs to be explained the factors of Potocco's model and others that are specific for a diaspora community and are realizing national interpellation as well. First, as Potocco concludes, the school system is one of the major factors for the majority group, as it is also for a diaspora community too, and that is why this research was to spend the most time in the main Slovenian Saturdays school. But furthermore, based on the field evidence for the Slovenian-Canadian case, it was found that national interpellation is not realized only in the school system, and therefore in the Slovenian school and a course to learn Slovenian as a second foreign language for adults, but more broadly in the educational field, in the areas of music, dance and sports activities. Children and adult choirs, dance groups and scouts are educational activities with much power and influence, treated as institutional organizations, equal to other organizations, although some of them exist under the Church system. Therefore it can be argued that in a diaspora community it is not only the school system that is realizing national interpellation but as one of the material factors of a diaspora community "state apparatus" to be included the whole educational field.

To determine the material factors specifically for a minority group, not ignored is Potocco's argument for intra-textual analysis of literature associated with documentary sources and his claim that national interpellation is not realized only with the literature as products, but through their literary content as well. This aspect is especially relevant for a diaspora community because in the field the archives or any other documents on the community activities are not available or insufficient, most likely because of the nature of the way it operates: volunteer work and informal processes. In this situation material of its development is widely available in literary works. And this way intra-textual analysis provides information about the development of the diaspora group. That is why it is still suggested it as a material factor for observation but only as a part of the whole area of the literary field - together with other activities, regarding to its extent of relevance while being observed. A highly relevant material factor for a diaspora community is also the use of its language. The research is not observing a majority group on its grounds of origin where the national interpellation would be realized in the use of the mother language. In a diaspora community it can be realized in two different languages, and even to choose Slovenian before English, the language of the environment, becomes a strong material factor for addressing the identity of country of origin. While Potocco diachronically analyzes written language, we must - based on the actual conditions of the Slovenian-Canadian Case - analyze the most commonly spoken language in informal situations when we deal with a diaspora group synchronically. The examination was of the community, in which actions are part of their family environment, how they spend their free time and holidays together, and celebrating religion. The most common collective activity of such an operation system is a so-called "banquet," event for the members of the community and their family members with Slovenian music and food as a tradition. Based on the field evidence, that national interpellation is strongly realized in popular situations outside the literary institution as well, like religion, music, culinary, sport and economy - that is why for a diaspora community there is as added material factor for this area under Other.

Based on a thorough analysis of the Slovenian-Canadian case activities in 2014 and 2015 we determine material factors for realization of national interpellation for diaspora communities if we examine them synchronically: socio-institutional context (interconnection of institutions), education, literary institution (publishing market, media, literary system (intra/extra-textual analysis)), language use (written/spoken) and other (religion, music, economy, culinary, sport). 


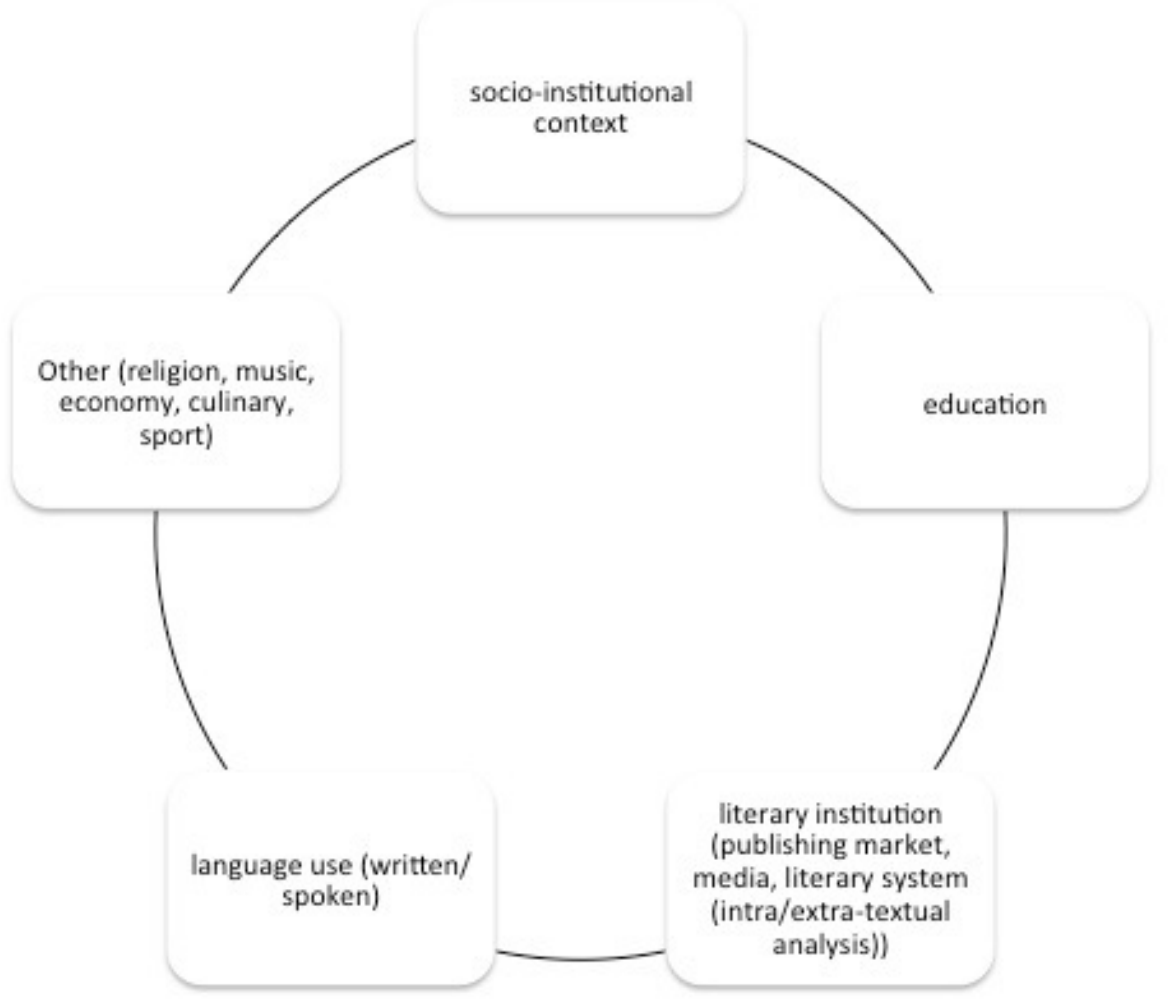

Model 2. Material factors of realizing the national interpellation in a diaspora community

But Potocco [39] warns: national interpellation "within a text always depends on the social, extra-textual codes of interpretation, since ideology can only interpellate as a socio-historical force imposed by the reader on a text". In other words, if we "translate" it into the school system; for national interpellation to be realized it is not enough that students come to school every week, but that the goals in the classrooms are effective and reached. Therefore we must always take care that the actions are successfully addressed.

\section{Reassessment}

The observed community is addressing its Slovenian identity in many ways through a sustained and steady volunteer movement, organizing cultural, music, sports and religious activities since the immigrants arrived in Canada. But as years go by, and after celebrating their 40th, 50th or even 60th anniversaries, the activities are declining on both their production and participation levels. It is observed fewer activities and smaller audiences, and the existing actions of addressing are weaker. Based on the "insider" status of the researcher, over time, it was able to suggest and implement additional actions, using a participatory design model. The researcher was most successful in the Slovenian Canadian bilingual Glasilo magazine, in the $6^{\text {th }}$ grade of the Slovenian School in Toronto and in the promotion of Slovenian language use. But the researcher influenced all of the existing material factors to some extent. After the participating period of 2014 and 2015, if we once again evaluate the ethno-linguistic vitality of the Slovenian-Canadian diaspora community using the Howard Giles et al. taxonomy, the study gets these results: 
Table 3. Vitality assessment of the Slovenian-Canadian case in Ontario for the period of 2014-2015

\begin{tabular}{|c|c|c|}
\hline Status variables & Demographic variables & Institutional support \\
\hline $\begin{array}{l}\text { Advocacy status } \\
\mathbf{M} \mathbf{M}\end{array}$ & $\begin{array}{c}\text { National territory } \\
\text { MH MH }\end{array}$ & $\begin{array}{c}\text { National or their own institutional support } \\
\text { M MH }\end{array}$ \\
\hline $\begin{array}{l}\text { Political status } \\
\text { ML MH }\end{array}$ & Concentration, proportion & $\begin{array}{l}\text { Mass media } \\
\text { ML MH }\end{array}$ \\
\hline $\begin{array}{l}\text { Economic status } \\
\text { M MH }\end{array}$ & $\begin{array}{c}\text { Absolute } \\
/\end{array}$ & $\begin{array}{l}\text { Education } \\
\text { ML MH }\end{array}$ \\
\hline $\begin{array}{l}\text { Social status } \\
\quad \mathbf{M} \mathbf{M}\end{array}$ & $\begin{array}{c}\text { Birth rate } \\
/\end{array}$ & $\begin{array}{l}\text { Government services } \\
\text { ML ML }\end{array}$ \\
\hline $\begin{array}{l}\text { Socio-historical status } \\
\text { M M }\end{array}$ & $\underset{/}{\text { Mixed Marriages }}$ & $\begin{array}{l}\text { Industry } \\
\mathbf{L} \mathbf{M}\end{array}$ \\
\hline \multirow[t]{4}{*}{ Language status: - within L M - without L L } & Immigration, emigration & $\begin{array}{c}\text { Religion } \\
\text { M M }\end{array}$ \\
\hline & & $\begin{array}{l}\text { Culture } \\
\text { M M }\end{array}$ \\
\hline & & $\begin{array}{c}\text { Contacts with country of origin } \\
\text { M MH }\end{array}$ \\
\hline & VITALITY ASSESSMENT: & \\
\hline М М-MH & $1 /$ & $M L M$ \\
\hline
\end{tabular}

Legend: $\mathrm{L}=$ low, $\mathrm{ML}=$ medium low, $\mathrm{M}=$ medium, $\mathrm{MH}=$ medium high, $\mathrm{H}=$ high vitality Pilot vitality assessment $=$ first mark; vitality assessment = second mark

Based on the fact that in 2014 and 2015 no laws or advocacy laws in Slovenia, related to Slovenians abroad were changed, neither were migration policy in Canada or any acts inside of the Slovenian-Canadian community, the mark for advocacy status stayed the same as in the pilot assessment, where legislation was especially focused. But the political status was assessed 2 marks higher, based on the evidence from the field. In the spring elections of 2015 the principal organization, VSKO, after many years of the Marjan Kočarič presidency, there was elected a new president, Milan Vinčec, which means the community got another political representative, while Marjan Kolarič since then is still the Slovenian Representative for Canada at Government of the Republic of Slovenia. Before that, he served in the both functions. Another reason is that the principal organization, VSKO, after many years again organized a luncheon to gather money for Slovenian radio and Glasilo magazine, which happened in southern Ontario region, in Hamilton as reported by Čuš [40] in Glasilo magazine, which demonstrates a successful relationship between the VSKO and the SKON in the southern Ontario region in the luncheon in a very long time (it is usually held in Toronto's region or the northern Ontario region). It was also an effect of the fieldwork in the Glasilo magazine in 2014 and 2015 whereby the editorial team was increased from 6 to 40 members. These individuals are typically presidents of the organizations themselves, or other board members, so we can count these as actions of national interpellation from the VSKO media field to the political status as well. But most importantly for increasing the vitality of the political variable is the appointment of a Slovenian ambassador again in 2014 after a lapse of several years [41].

The mark for economic status was also raised. Since January 2016 both Slovenian banks were amalgamated to form the Moya Financial Credit Union, which was developed during the period of observation in 2015. In the fall of 2014 the Canadian Slovenian Chamber of Commerce (CSCC) was reinvigorated with a renewed board and program after few years of more limited activity and since then has organized many gatherings and educational events for Slovenian businessmen in Toronto. This is why there is an increased the mark for industry as well, because it was realized that interpellation of Slovenian national identity is addressed strongly, through choosing a Slovenian company in preference to others, or in connecting among themselves for business activities and education. The companies are also often generous sponsors for the actions/events in the community at large.

Language status within the community in 2014-2015 was rated for a higher mark than in the pilot assessment. In the institutional operation of the community the researcher has always promoted the use of the Slovenian language, if it was at all possible depending on the interlocutor's language knowledge. For example, at the annual VSKO meeting of organizations in 2014, despite the whole 
encounter being conducted in English, it was reported in Slovenian in the Glasilo magazine. In 2015 the editors added a section called "Page for the Slovenian Language" to the magazine and always attempted to keep an even balance between Slovenian and English language articles. Outside of formal situations the researcher promoted the use of Slovenian in interactions with all individuals, if possible, and twice a week in the last existing Slovenian grocery store. As for the material factor of national interpellation for the (Slovenian) language use the researcher was able to apply actions in broadest range (of individuals) and concluded that the vitality assessment in this area is for a higher mark, that is for the use of the Slovenian language within the community. There were no other changes in the use of the Slovenian language outside of the community. There is none, as in the pilot assessment.

For the institutional support variables the research increased the mark in many areas. For the first variable, national or their own institutional support, the mark was increased from medium to medium high vitality, because within the existing circle of Slovenian organizations in Ontario after many years the researcher was helped to set up another one in 2015 called Preskok. For the ethno-linguistic vitality of the Slovenian-Canadian diaspora community it is highly relevant because it gathers members that have immigrated to Canada after the 2008 economic crisis in Slovenia, starting with a one year working visa in the programme of Citizenship and Immigration Canada (as the researcher did), that offers each year 100 individuals from Slovenia a working chance to gain experience in Canada. There are numerous temporary workers among them, but some manage to come through the processes of qualifying for permanent residency and starting new lives in Canada, which is difficult, especially in Ontario. It is easier in other provinces of Canada like Alberta or Saskatchewan. Most likely these individuals do not get involved in the existing community (rather more in the Canadian environment) because of having a completely different motivation for moving or different background-traditions in the country of origin in the matter of their own identity state compared to the previously existing community. Usually they participate when they first come to Canada and only at the major events for youth, for example Pečenkafest in Slovenski Park. But they do have their own gatherings in downtown Toronto, when they get together for movie nights and discussions on actual private conditions and exchanges of opinion on living there. In 2016 Preskok signed a brotherhood contract with Slovenski Dom, an organization established in Toronto over 50 years ago, and started working together, which has made them a part of the existing community.

The vitality of the mass media variable has been increased by 2 marks compared to the pilot assessment, because of deepened examinations of the actual conditions in the field. The researcher examined Radio Glas of
Slovenians in Canada (operated by VSKO) as a strong and powerful institution for addressing the Slovenian national interpellation through Slovenian music and language (after many years the show is still completely performed in Slovenian language only). They also report the news from Slovenia, on events that happened in the community and promote future events and actions. Their strong (volunteer) technical and editorial team, partly funded from Slovenia is unconsciously operating according to a participatory design model, since they include all possible aspects in the show structure: including members of the community who pay a small fee to issue messages of congratulations or memorials or to promote events in the community, and both editors are routinely present at most, if not all, events in the community.

In the pilot assessment the so-called "newsletters" were overlooked, the regularly issued 4-page media tools in the language of the environment, English, but which often happen to include articles in Slovenian as well. They are highly relevant and active written texts, printed or electronic versions or both, strongly represented in the community in the past, and in the period of 2014-2015, for example Our Story of the Canadian Slovenian Historical Society, and Newsletter of Krek Slovenian Credit Union through to 2016. A few times a year they are sent electronically to the list of members that are connected with the organization in some way or other. Printed versions could be found, for example, the Krek newsletter at their bank counters, and Our Story in both Slovenian Parishes. There is also News of the Slovenian Seniors residence and nursing home Dom Lipa. At least two Slovenian parishes publish printed news weekly, Vestnik from the parish in Hamilton (issued electronically as well), and Župnijski list from one of the Torontonian parishes. Both are strictly bilingual including contents reports, news, promoting actions in the community, excerpts from sermons or paragraphs from the Bible, and advertisements. Glasilo magazine, the main publication for Slovenians in Canada, published by VSKO celebrating its 20th anniversary in 2017 and partly funded from Slovenia, was in very poor shape in 2014. The researcher took over the magazine and revamped its content during the expansion of the editorial team from 6 to approximately 40 regular members sending articles and images. As Editor-in-Chief through 2014 and 2015, the researcher was always promoting the magazine in the community wherever possible. Based on all the evidence from the field, the researcher activity increased the mark of mass media variable in the Slovenian Community in Canada to the mark of medium high vitality.

In 2014-2015 there were no major changes in the field of education. The choirs and dance groups were still active as they were with the pilot assessment, except that the Slovenian School operating in Toronto for many years shortened its timetable by one hour for the 2014/2015 school year. But the school, which serves 100 students a 
year, established working group on the curriculum in 2014, and both Slovenian schools under the churches in Toronto and Hamilton with the cooperation of the Republic of Slovenia Office for Slovenians Abroad and the Slovenian Center for Slovene as a Second/Foreign Language organized a seminar on teaching Slovenian as second foreign language for Slovenian volunteer diaspora teachers in Ontario. The seminar was usually organized for teachers from the Slovenian diaspora communities all over the world in Ljubljana, the capital city of Slovenia, so this was a major one-time educational event in 2014. As a teacher of the 6th grade in the Toronto area the researcher was also able to effectively plan a school day of Language and Literature in two school years for 20 students and managed to develop guidelines to increase the vitality in the school system that it was have derived from intercultural pragmatics. The school had no existing curriculum; therefore the prepared lessons used the intercultural approach and model TILKA by Mikolič [42] and models for teaching Slovenian as L1 and L2. The intercultural model lesson plan for teaching language and literature was used with the realization of national interpellation for diaspora voluntary schools and verified it with four cases, on the production and participation level, and proved that the model works. It was presented to the Working group on the Curriculum of the Slovenian school Toronto and suggested as the universal curriculum for all grades. Based on all these actions and more in the field the researcher increased the mark for vitality assessment 2014-2015 of the Education variable at 2 marks higher, from medium low to medium high.

In the period of observation there were no essential changes in the field of government services, religion or culture. It is only possible for these variables to change very rarely and very slowly especially in a volunteer based work community. The VSKO Information Centre is still open on Saturdays as in previous years but it remains more or less passive (only phone calls, no internet activity), however the services are running as in previous years (the promotion of events, selling tickets, religion activities).

Contacts with the country of origin were assigned a higher mark. What was missed in the pilot assessment is that relations between the Slovenian Community in Canada and Slovenia through the Slovenian Embassy had been very active despite Ottawa's location $450 \mathrm{~km}(\sim 5$ hours travel) northeast of Toronto. The embassy staff represents the country of origin in most of the activities in the Slovenian Community in Toronto and southern Ontario region and worked together with the various organizations wherever and whenever possible during 2014 and 2015. A relevant act of enhanced contact between the diaspora community and country of origin was also a visit by the Slovenian Minister of Slovenians Abroad, Gorazd Žmavc in the spring of 2016. As reported in Glasilo by Čuš [43] he visited Ontario and the Slovenian communities in Vancouver, Edmonton, Calgary and Winnipeg as well.
Even the Glasilo magazine got involved with a correspondent from Ljubljana and some Slovenian media like radio Koper and Veseljak thanks to radio Glas which has regular contacts with media of the country of origin through regular visits by the editor Marija Ahačič Pollak to Slovenia. In 2015 there was also a group visit by students of the Toronto Slovenian School to Slovenia as their graduation trip which still happens every two years. And after the examination and discussions with individuals in the field it can be claimed that visits of Slovenians from Canada to their home country are more numerous than expected both individually and in private matters, visiting family, while some do so regularly, and some only occasionally.

In a common node for the period of 2014-2015 we have assessed status variables as medium high vitality, variables of institutional support from pilot medium low to medium high vitality, however unable to evaluate demographic variables in the field. The ethno-linguistic vitality of the Slovenian Diaspora community in Ontario was successfully assessed, based on actual results through observation of and by participation in the minority group closely for a period of two years and after returning to the country of origin analyzing the experiences objectively. It is assumed that the assessment brings comprehensive knowledge of the Slovenian Diaspora community in Ontario, Canada to both, the country of origin and the country of acceptance.

\section{Conclusions}

In the proposed original approach to how to examine a diaspora community the researcher used literary history methods, so no longer dealing only with observations any more, but with acts of addressing and empowering the national interpellation according to Potocco (2012). The model of material factors of realizing the national interpellation in the field work for a diaspora community works as an effective systematic tool to participate and influence active factors where national interpellation is addressed, editing these actions, and implementing new ones. That the literary model was effective and proven with the reassessment by the Giles et. al. model to compare results with the pilot assessment, and the goals for (at least partial) enhancement were achieved. The research recommends this approach for empowerment of national identity of the Slovenian diaspora as well as minorities of other nations.

\section{REFERENCES}

[1] Kocjančič, Cvetka. Slovenes. The Canadian Encyclopedia. 2010. Online available from: 
http://www.thecanadianencyclopedia.ca/en/article/slovenes/

[2] Kocjančič, Cvetka. Slovenes. The Canadian Encyclopedia. 2010. Online available from:

http://www.thecanadianencyclopedia.ca/en/article/slovenes/

[3] Kocjančič, Cvetka. Razmišjanje v senci kanadskega javorja. Unpublished article, written for Delo newspaper, 1999. Available from Kocjančič family archive in 2013.

[4] Plevnik, Jože. Cerkev in slovenska identiteta v Kanadi. 1997. Online available from: http://www.dlib.si/?URN=URN:NBN:SI:DOC-UGH6ENF 2.

[5] Genorio, Rado. Slovenci v Kanadi. Institut za geografijo Univerze Edvarda Kardelja, Ljubljana, 1989, 142.

[6] Jurak, Mirko. Kanada. Slovenska izseljenska književnost 2: Severna Amerika. Glušič Helga et al. SAZU, Ljubljana, 1999, 320-321.

[7] Žitnik Serafin, Janja. Večkulturna Slovenija: položaj migrantske književnosti in kulture $\mathrm{v}$ slovenskem prostoru. Zbirka Migracije 15, ZRC. ZRC SAZU, Ljubljana, 2008, 56.

[8] Strle, Urška. Slovenci v Kanadi: izseljevanje skozi prizmo življenjskih zgodb. Doctoral Dissertation. Faculty of Arts, Department of History, University of Ljubljana, 2009, 4-6.

[9] Strle, Urška. Slovenians in Canada: An Oral History perspective. In: Migrating Memories: Central Europe in Canada. Volume 2 - Oral Histories. Central European Association for Canadian Studies, Brno, 2010, 359.

[10] Dewing, Michael. Canadian Multiculturalism. Library of Parliament, Ottawa, 2009, 1-9. Available from: https://bdp.parl.ca/content/lop/ResearchPublications/2009-2 0-e.pdf

[11] Dewing, Michael. Canadian Multiculturalism. Library of Parliament, Ottawa, 2009, 3. Available from: https://bdp.parl.ca/content/lop/ResearchPublications/2009-2 0-e.pdf

[12] Kymlicka, Will. The current State of Multiculturalism in Canada and research themes on Canadian Multiculturalism 2008-2010. Minister of Public Work and Government services, 2010, 31. Online available from: Http://www.cic.gc.ca/english/pdf/pub/multi-state.pdf.

[13] Strle, Urška. Slovenians in Canada: An Oral History perspective. In: Migrating Memories: Central Europe in Canada. Volume 2 - Oral Histories. Central European Association for Canadian Studies, Brno, 2010, 4-6.

[14] James, William. Pragmatizem. Krtina, Ljubljana, 2002, 214.

[15] James, William. Pragmatizem. Krtina, Ljubljana, 2002, 220.

[16] Šimenc, Marjan. William James, pragmatizem in resnica. In: Pragmatizem. William James, 2002, 223.

[17] James, William. Pragmatizem. Krtina, Ljubljana, 2002, 123.

[18] James, William. Pragmatizem. Krtina, Ljubljana, 2002, 39.

[19] Nećak Luk, Albina et al.. Medetnični odnosi in etnična identiteta $\mathrm{v}$ slovenskem etničnem prostoru. I, izsledki projekta. Inštitut za narodnostna vprašanja, Ljubljana, 1998, 35-36.
[20] Participatory Design. 2015. Online available from: http://en.wikipedia.org/wiki/Participatory_design.

[21] Corbin Dwyer, Sonya and Jennifer L. Buckle. The Space Between: On being an Insider-Outsider in Qualitative Research. 2009, 62. Online available from: http://ejournals.library.ualberta.ca/index.php/ijqm/article/do wnload/2981/5198.

[22] James, William. Pragmatizem. Krtina, Ljubljana, 2002, 46.

[23] Corbin Dwyer, Sonya and Jennifer L. Buckle. The Space Between: On being an Insider-Outsider in Qualitative Research. 2009, 55. Online available from: http://ejournals.library.ualberta.ca/index.php/ijqm/article/do wnload/2981/5198.

[24] Strle, Urška. Slovenci v Kanadi: izseljevanje skozi prizmo življenjskih zgodb. Doctoral Dissertation. Faculty of Arts, Department of History, University of Ljubljana, 2009, 172-173.

[25] Corbin Dwyer, Sonya and Jennifer L. Buckle. The Space Between: On being an Insider-Outsider in Qualitative Research. 2009, 58. Online available from: http://ejournals.library.ualberta.ca/index.php/ijqm/article/do wnload/2981/5198.

[26] Corbin Dwyer, Sonya and Jennifer L. Buckle. The Space Between: On being an Insider-Outsider in Qualitative Research. 2009, 57-58. Online available from: http://ejournals.library.ualberta.ca/index.php/ijqm/article/do wnload/2981/5198.

[27] Corbin Dwyer, Sonya and Jennifer L. Buckle. The Space Between: On being an Insider-Outsider in Qualitative Research. 2009, 60. Online available from: http://ejournals.library.ualberta.ca/index.php/ijqm/article/do wnload/2981/5198.

[28] Corbin Dwyer, Sonya and Jennifer L. Buckle. The Space Between: On being an Insider-Outsider in Qualitative Research. 2009, 62. Online available from: http://ejournals.library.ualberta.ca/index.php/ijqm/article/do wnload/2981/5198.

[29] Čuš, Alenka. Družbeni in prostorski vidiki identitete in jezikovne prakse (primer Slovencev v Torontu). Seminar work. Univerza na Primorskem, Fakulteta za humanistične študije, Koper, 2013.

[30] Žitnik Serafin, Janja. Večkulturna Slovenija: položaj migrantske književnosti in kulture $\mathrm{v}$ slovenskem prostoru. Zbirka Migracije 15, ZRC. ZRC SAZU, Ljubljana, 2008, 192.

[31] Strle, Urška. Slovenci v Kanadi: izseljevanje skozi prizmo življenjskih zgodb. Doctoral Dissertation. Faculty of Arts, Department of History, University of Ljubljana, 2009, 13.

[32] Muller, Michael and Allison Druin. Participatory Design: The Third Space in HCI. 2003, 11. Online available from: http://www.watson.ibm.com/cambridge/Technical_Reports/ 2010/TR2010.10\%20Participatory\%20Design\%20The\%20 Third\%20Space\%20in\%20HCI.pdf.

[33] Muller, Michael and Allison Druin. Participatory Design: The Third Space in HCI. 2003, 12. Online available from: http://www.watson.ibm.com/cambridge/Technical_Reports/ 
2010/TR2010.10\%20Participatory\%20Design $\% 20$ The $\% 20$ Third\%20Space $\% 20$ in $\% 20$ HCI.pdf.

[34] Muller, Michael and Allison Druin. Participatory Design: The Third Space in HCI. 2003, 12. Online available from: http://www.watson.ibm.com/cambridge/Technical_Reports/ 2010/TR2010.10\%20Participatory $\% 20$ Design $\% 20$ The $\% 20$ Third\%20Space\%20in\%20HCI.pdf.

[35] James, William. Pragmatizem. Krtina, Ljubljana, 2002, 40.

[36] Potocco, Marcello. Nacionalni imaginariji. Literarni imaginariji: različice nacionalnega poziva $\mathrm{v}$ literaturi in $\mathrm{v}$ literarnih kontekstih. Pedagoški inštitut, Ljubljana, 2012, 238.

[37] Lešnik, Bogdan. 1997. Subjekt v analizi. ISH - Fakulteta za podiplomski humanistični študij, Ljubljana, 1997, 23-25.

[38] Potocco, Marcello. Nacionalni imaginariji. Literarni imaginariji: različice nacionalnega poziva $\mathrm{v}$ literaturi in $\mathrm{v}$ literarnih kontekstih. Pedagoški inštitut, Ljubljana, 2012, 37.
[39] Potocco, Marcello. Nacionalni imaginariji. Literarni imaginariji: različice nacionalnega poziva $\mathrm{v}$ literaturi in $\mathrm{v}$ literarnih kontekstih. Pedagoški inštitut, Ljubljana, 2012, 241

[40] Čuš, Alenka. Dobrodelno kosilo VSKO Odbora v Hamiltonu. In: Glasilo kanadskih Slovencev. Vol. 21, no. 15. Vseslovenski kulturni Odbor, Toronto, 2016, 4-5.

[41] Čuš, Alenka. Nov Veleposlanik, dr. Marjan Cencen, na delovnem mestu v Ottawi. Interview in: Glasilo kanadskih Slovencev. Vol. 19, no. 11. Toronto, Vseslovenski kulturni Odbor, Toronto, 2014, 15-21.

[42] Mikolič, Vesna. Ethnic identity and intercultural awareness in modern language teaching. Tilka model for ethnic conflicts avoidance. Nova Science Publishers Inc., New York, 2015.

[43] Čuš, Alenka. Minister Gorazd Žmavc na obisku v Kanadi. In: Glasilo kanadskih Slovencev. Vol. 21, no. 17. Vseslovenski kulturni Odbor, Toronto, 2016, 26-27. 